\title{
Set-Off in International Economic Arbitration
}

\author{
by KLAUS PETER BERGER*
}

\section{INTRODUCTION}

IN EVERY developed legal system, cross-claims existing reciprocally between two parties may be set off against each other through unilateral declaration, judicial order or ex lege effect. ${ }^{1}$ Until recently, ${ }^{2}$ this institution has not received particular doctrinal attention in the context of international economic arbitration. While most arbitration rules contain provisions on counterclaims, only some of them deal with set-off ${ }^{3}$ even though both institutions bear a striking resemblance. ${ }^{4}$ Arbitration laws rarely contain rules on set-off. ${ }^{5}$ In the travaux préparatoires for the new German Arbitration Act that entered into force on 1 January 1998, the German legislature has stated that 'issues that due to their complexity do not lend themselves for statutory regulation [in an arbitration act], such as multiparty

* Professor of Law, Institute for International Business Law, Center for Transnational Law (CENTRAL), Münster University, Germany. The article is based on a presentation given at a meeting of the Zurich Group of the Swiss Arbitration Association (ASA) on 23 February 1998. Special thanks go to Marc Blessing, Siegfried Elsing, Pierre Karrer, Jan Paulsson, Johnny Veeder and Daniel Wehrli for their comments on earlier drafts of the article.

1 See ICC Award No. 3540, reprinted in Collection of ICC Arbitral Awards (eds. Jarvin and Derains) (19741985, 1990) at pp. 105, 112 (English translation) and pp. 399, 403 (French original); ICC Award No. 5971 in (1995) 13 ASA Bulletin at p. 728; Derham, Set-Off (1996, 2nd ed.) at p. 1, emphasizing that set-off should not be confused with situations in which, in the absence of any cross-demand, the damages payable by the respondent may be reduced due to a benefit incidentally accruing to the claimant as a result of the respondent's breach; $c f$. also for a case of automatic deduction under common law Lord Mansfield in Dale v. Sollet [1767] 4 Burr. 2133; see for this important differentiation under German law Berger, Der Aufrechnungsvertrag (1996) at pp. 190 et seq.

z See for recent comments on 'set-off and arbitration' Poudret, 'Compensation et Arbitrage' in Le Droit en Action (eds Rapp and Jaccard) (Lausanne 1996) at p. 361; Reiner, 'Aufrechnung trotz (Fehlens einer) Schiedsvereinbarung nach österreichischem Recht' in Festschrift Karl Hempel (Vienna 1997) at p. 108; Bonzanigo, 'Il nuovo regolamento di arbitrato di Lugano: presentazione e temi scelti' in II Tekken e il Diorite (eds Caimi, Cometta, Corti) (1997) at pp. 93, 106 et seq.

3 See Article 19(3) UNCITRAL Arbitration Rules; Article 30(5) ICC Rules of Arbitration in force as of 1 January 1998 (ICC Publication No. 581); Article 42(c) WIPO Arbitration rules; Article 27 International Arbitration Rules of the Zurich Chamber of Commerce, see infra V(b)(iii).

4 See infra III.

5 See for a discussion of Article 29 of the Swiss Concordat infra V(b)(i).

ARBITRATION INTERNATIONAL, Vol. 15, No. 1

(C) LCIA, 1999 
arbitration or set-off, have not been dealt with in the new law'. ${ }^{6}$ During the deliberations of the UNCITRAL Model Law on International Commercial Arbitration, the Czechoslovakian delegation suggested a provision stating that until the end of the hearing, the tribunal would have the right 'to conduct proceedings also on counterclaims .... and on claims presented as set-offs in the form of a defence'. ${ }^{7}$ This proposal did not receive further consideration. The Working Group assumed that provisions dealing with counterclaims 8 'would apply [mutatis mutandis] to a claim relied on by the respondent for the purpose of a set-off'. ${ }^{9}$

The reason why arbitral institutions, domestic legislatures and the UNCITRAL Working Group alike are reluctant to deal with set-off in the context of international arbitration is rooted in the particular nature of this legal institution. Set-off may have a substantive or procedural nature, depending on the applicable law. Even within a given legal system, there may be different types of set-off, having either a procedural or a substantive nature. Domestic laws may also impose quite distinct requirements on the effectiveness of this defence. The complexity of the subject has led to the conclusion that even today, set-off is 'an institution which does not seem to have revealed all its mysteries'. ${ }^{10}$ In the context of international arbitration, additional intricate problems may arise when the cross-claim is not subject to the same arbitration clause. Also, the cost aspect may add a particular coloration to the problem. For all of these reasons, arbitral institutions, domestic legislatures and the UNCITRAL Working Group, eager to ensure the 'userfriendliness' of their respective rules by ensuring a minimum of interference with domestic laws, have refrained from tackling the issue of set-off in international economic arbitration, where aspects of procedural and substantive law are inextricably intertwined.

This regulatory sparseness and the substantive and procedural intricacies of setoff make it all the more important that international arbitrators have a fixed arsenal of generally accepted principles relating to the historical background, to the relationship between set-off and counterclaim, to conflict of laws issues, to the procedural admissibility of the plea in the arbitration and to the costs of set-off. ${ }^{11}$

6 'Bericht mit einem Diskussionsentwurf zur Neufassung des Zehnten Buches der ZPO' (1994) at p. 14 (emphasis added) (ed. Kommission zur Neuordnung des Schiedsverfahrensrechts).

UN Doc. A/CN.9/263 (19 March 1985), 'C. Comments on additional points', No. 3.

8 Article 2(f) concerning the analogous application of provisions dealing with 'a claim' to 'a counter-claim' was inserted into the Model Law at the last minute of the deliberations in the UNCITRAL Working Group, see the Commission Report UN Doc. A/40/17 (21 August 1985), No. 327; cf. also infra III.

9 UN Doc. A/CN.9/264 (25 March 1985), Article 23, No. 7 in fine.

10 Ndoko, 'Les mystères de la compensation' in (1991) Rev. dr. civ. at p. 661 .

11 See Mustill and Boyd, Commercial Arbitration (1989, 2nd ed.) at p. 129, stating that the co-existence of asserted claims, set-offs and counterclaims may give rise to difficult theoretical and practical problems 'upon which the reported cases give little guidance'. 


\section{THE HISTORICAL DEVELOPMENT OF SET-OFF}

In the field of set-off more than in others, the historical perspective helps to understand the different concepts of set-off that exist in the various jurisdictions.

\section{(a) Set-Off in Roman Law}

The origins of the law of set-off can be traced back to ancient Roman law. The initial strong legal and procedural formalism of classical Roman law forbade any set-off even of claims stemming from the same contract. Instead, it required the specific performance of any obligation until a rescript of Emperor Marcus Aurelius (161-180) granted the plea of 'exceptio doli' when the claimant refused to deduct from his claim the amount of a claim that the respondent had against him. From then on, the right of set-off was no longer limited to actions in equity ('bonae fidei iudiciis'), in which the respondent could raise the plea of set-off when his claim arose out of the same contract ('eadem causa'). It was also granted in actions of strict law ('iudicia stricti iuris') and irrespective of whether the claims were born out of the same contract. ${ }^{12}$ Later, the Emperor Justinian ordered that the plea of set-off was to be applied to all actions, irrespective of their procedural or substantive qualification. ${ }^{13}$

\section{(b) Set-Off in Civil Law}

The recognition of set-off as a generally acknowledged remedy of Roman law was the basis for the development of set-off as a legal principle in civil law jurisdictions ('Aufrechnung', 'Verrechnung', 'compensation', 'verrekening', 'compensación', 'compensazione' ). ${ }^{14}$ The long-standing dispute whether set-off is of a procedural or substantive law nature was finally decided in favour of the latter view. ${ }^{15}$ It was argued that whenever equity ('aequitas', 'Billigkeit') requires the setting-off of mutual claims, set-off through unilateral extra-judicial declaration by one of the parties should be allowed. ${ }^{16}$ In the jurisdictions of the formerly communist countries as well, the 'remarkable development of this legal institution and of its

12 'Sed et in strictis iudiciis ex rescripto divi Marci opposita doli mali exceptione compensatio inducebatur', cf. Zimmermann, The Law of Obligations, Roman Foundations of the Civilian Tradition (1990) at p. 761.

13 cf. Appleton, Histoire de la Compensation en Droit Romain (1895) at p. 769; Zimmerman, op. cit. at pp. 766 et seq.; Dullinger, Handbuch der Aufrechnung (1995) at p. 148.

14 cf. for French law Articles 1289 et seq. Code Civil ('compensation légale'); for Dutch law Articles 6:127 et seq. Dutch Civil Code (Burgerlijk Wetboek); for Spanish law Articles 1195 Codigo Civil; for Swiss law Articles 120 et seq. of the Swiss Law of Obligations and Article 148(3) of the Swiss Federal Law on Private International Law; for Italian law Article 124.1 Codice Civile; cf. also Articles 1672 et seq. Code Civil du Québec; s. 432 of the Civil Code of the former German Democratic Republic; see for American law Edmonds v. Stratton, Mo.App. 457 SW 2d 228 at 232 and s. 2-717 UCC; $c$ f. also the survey by Wild, Die Verrechnung im internationalen Privatrecht (1992) at pp. 86 et seq.; cf. generally the survey by Wood, English and International Set-Off (1989) Nos. 24-1 et seq.

15 See J. Goldschmidt in (1899) 15 Archiv für Bürgerliches Recht at pp. 153, 156, n. 3: "The question whether set-off may be effected through a unilateral, extra-judicial declaration belongs to the most controversial issues' (translation by the author).

${ }^{16}$ See Kohler, 'Kompensation und Prozess' in (1894) 20 Zeitschrift für Zivilproze $\beta$ at pp. 1, 11. 
place in the legal regulation of international economic relations' was acknowledged and work towards unification of the law of set-off was commenced within the Council for Mutual Economic Cooperation. ${ }^{17}$ Today, the new Civil Code of the Russian Federation has incorporated the remedy of set-off in Articles 410 et seq.

There was, however, one important difference in the development of the law of set-off in civil law jurisdictions. In some countries such as France (for the 'compensation légale' under Articles 1289 et seq. of the Code Civil), ${ }^{18}$ Belgium and Spain, the setting-off of two claims is effected ipso iure, without any declaration by one of the parties, while in others such as Germany, the Netherlands, Switzerland, Japan, Korea and the Scandinavian countries, set-off always requires a declaration by one of the parties. This difference in construction is mitigated by the fact that, even where the set-off is effected ipso iure, the debtor has to invoke the set-off in order to make it relevant for the judge. ${ }^{19}$ Still, the question as to the ipso iure effect of set-off has led to considerable confusion. In some jurisdictions, such as South Africa, the issue whether set-off has an ipso iure effect or requires a declaration by one of the parties is still disputed today. ${ }^{20}$ In Austria, the legislature assumed an ipso iure effect of the set-off provisions of the Austrian Civil Code. However, since this legislative intent was not clearly expressed in the law itself, Austrian doctrine today requires a declaration of set-off by the debtor. It is an unfortunate development of the law that the assumption of an ipso iure effect of set-off, which divides the civil law jurisdictions, was in fact the result of a misconception of the Roman principle 'compensatio fit ipso iure' rather than of a coherent legal evolution. ${ }^{21}$

\section{(c) Set-Off in Common Law}

The equitable character of set-off was the starting point for the development of set-off in common law. The plea of set-off was first granted as 'equitable set-off' of claims flowing out of the same or closely related transactions by the courts

17 Strohbach, in 'Grundzüge einer wissenschaftlichen Konzeption des allgemeinen Teils der rechtlichen Regelung internationaler Wirtschaftsverträge zwischen den Organisationen der Mitgliedsländer des RGW'. (ed. Akademie für Staats- und Rechtswissenschaften der DDR) (1986) at pp. 55, 56. See Article 1290 Code Civil: 'La compensation s'opère de plein droit par la seule force de la loi ...'

19 See for French law Terré, Siruler and Lequette, Droit Civil (1993,5th ed.) at p. 984, hinting at the principle of French procedural law contained in Article 7 of the Nouveau Code de Procédure Civil according to which the judge 'ne peut pas fonder sa décision sur les faits qui ne sont pas dans le débat'; see also Schlosser, Das Recht der internationalen privaten Schiedsgerichtsbarkeit (1989, 2nd ed.) No. 399. Zimmermann, supra n. 12, at p. 761 .

21 See E. Bucher, 'Rechtsvergleichende und kollisionsrechtliche Bemerkungen zur Verrechnung (Kompensation)' in Mélanges en L'Honneur d' Alfred E. von Overbeck (1990) at pp. 701, 706; cf. also Zimmerman, supra n. 12, at p. 767; in fact, the ipso iure effect of set-off was introduced through an error of the Glossator Martinus (Martinus, Glossa ad c.4 c.h.t. de compens. 4, 31; ad $\S 30$ i. de act. 4, 6; but see Glossator Azo, Summa Azonis h.t. $\S 13$ ) that found its way into various domestic laws; see Crome, System des deutschen Bürgerlichen Rechts, Vol. 2 (1902) at p. 288, n. 7. 
of equity, ${ }^{22}$ while the common law courts adhered to the concept of abatement ${ }^{23}$ or recoupment. ${ }^{24}$ Later, set-off was allowed at law in England under Statutes of Set-off enacted in 1729 and $1735 .{ }^{25}$ Today, the distinction between equitable set-off and set-off at law is said to be blurred. ${ }^{26}$ However, like the 'compensation légale' and 'compensation judiciaire' of French law, the two institutions have to be distinguished in terms of both prerequisites and legal nature.

The 'independent' set-off at law under the Statutes just mentioned is available only for mutual debts which are capable of being liquidated or ascertained with precision, including liquidated damages, e.g. those arising out of a liquidated damages clause. ${ }^{27}$ This type of set-off does not require any relation between the transactions out of which the claims arise. ${ }^{28}$ Set-off at law is a purely procedural defence, i.e. a procedure for taking an account of the balance due between the parties. ${ }^{29}$ There is thus no set-off at law without legal proceedings. ${ }^{30}$ Even when invoked by the respondent during the proceedings, claim and cross-claim as two separate and distinct debts remain in existence until there is a judgment for a setoff. Consequently, set-off at law cannot be invoked unilaterally by one of the

22 See Rawson v. Samuel [1841] Cr.\&Ph. 161; Supreme Court of Judicature Act 1873, s. 24; Supreme Court of Judicature Consolidation Act 1925, ss. 38, 41; Supreme Court Act 1981, s. 49; cf. also Chitty on Contracts (1994, 27th ed.) No. 28-090 in fine; Derham, supra n. 1, at pp. 40 et seq.

23 The plea of abatement was developed as a substantive defence of common law leading to the deduction of the plaintiff's claim primarily in sales and labour contracts, Mondel v. Steel, [1835-42] All ER 511; Aries Tanker Corporation v. Total Transport Ltd [1977] 1 All ER 398; cf. also English Sale of Goods Act 1979, s. $53(1)(a)$.

24 The defence of recoupment allowed the defendant to show, for the purpose of reducing or defeating the plaintiff's recovery, some facts arising out of the transaction sued upon which would have founded an independent action in the defendant's favour, Pennsylvania RR v. Miller [1941] 124 F. 2d 160; see James and Hazard, Civil Procedure (1977, 2nd ed.), § 10.14; Waterman, Set-off, Recoupment and Counterclaim (1872, 2nd ed.) $\$ 302$ et seq.

25 (1729) 2 Geo. II c. 22 s. 13; (1735) 8 Geo. II c. 24 s. 5; repeal of these Statutes by the Civil Procedure Acts Repeal Act of 1879 did not affect the right of set-off conferred by these Statutes, $c f$. Hanak v. Green [1958] 2 QB 9 at 22; see generally Rosenberg, Weinstein, Smit and Korn, Elements of Civil Procedure (1976, 3rd ed.) at p. 427; Derham, supra n. 1, at pp. 9 et seq.

26 See Clark and Surbeck, 'The Pleading of Counter-Claims' in (1928) 37 Yale $I J$ at pp. 300 et seq.; Wood, supra n. 14, No. 1-12; British Anzani (Felixstowe) Ltd v. International Marine Management (UK) Ltd [1979] 2 All ER 2163; Federal Commerce \& Navigation Co. Ltd v. Molena Alpha Inc. (The Nanfri) [1978] 3 All ER 1066 at 1078 (CA); Habib Bank Ltd v. Habib Bank AG [1981] 1 WLR 1265; cf. also Curson v. Arican Co. [1683] 1 Vern. 121; Chapman v. Tanner [1684] 1 Vern. 267, 23 ER 461; Chapman v. Derby [1689] 2 Vern. 117, 23 ER 684; Peters v. Soame [1701] 2 Vern. 428, 23 ER 874; Lord Lanesborough v. Jones [1716] 1 P Wms 325, 24 ER 409; Green v. Farmer [1768] 4 Burr. 2214, 98 ER 154; cf. generally McCracken, The Banker's Remedy of Set-Off (1993) at pp. 48 et seq.; Kegel, Probleme der Aufrechnung (1938) at pp. 11 et seq.; Eujen, Die Aufrechnung im internationalen Verkehr zwischen Deutschland, Frankreich und England (1975) at pp. 20 et seq.

27 Stooke v. Taylor [1880] 5 QB 569; Aectra Refining and Marketing Inc. v. Exmar NV (The 'New Vanguard') [1995] Lloyd's Rep. 191 at 192; Derham, supra n. 1, at p. 13.

28 The 'New Vanguard', ibid. at p. 200; In re Daintry [1900] 1 QB 546; Derham, supra n. 1, at p. 319.

29 The 'New Vanguard', ibid. at p. 200.

so See Talbot v. Frere [1878] 9 Ch.D. 568 at 573 : '... There could not be a set-off until action brought and set-off pleaded'. 
parties outside judicial or arbitral proceedings. ${ }^{31}$ Equitable or 'transaction'32 set-off, on the other hand, operates as a true, substantive defence against the respondent's liability to pay a debt otherwise due. It may be invoked independently of any order of a court or arbitral tribunal. ${ }^{33}$ Also, the cross-claim, whether contractual or tortious, need not arise out of the same contract as the claim, provided that 'it is inseparably connected with the transaction giving rise to the claim so that the title of the plaintiff at law to prosecute his demand is impeached'. ${ }^{34}$ Opinions are still divided whether, similarly to the German, Swiss or Dutch notion of set-off, equitable set-off requires the debtor to 'exercise' or 'declare' the set-off or whether the claims remain in existence between the parties, irrespective of the debtor invoking the set-off, until extinguished by judgment or agreement. ${ }^{35}$

\section{SET-OFF AND COUNTERCLAIM}

When claims of money are at stake, which usually is the case in international economic arbitration, set-off and counterclaim are 'only a hair's-breadth away' 36 from each other. Both may be based on the same factual pattern, the co-existence of asserted claims between the parties. It is for this reason that a party invoking a set-off in an ICC-arbitration will have to pay an advance on costs as if it had raised a separate claim or counterclaim. ${ }^{37}$ Set-off in international economic arbitration is therefore sometimes regarded as a 'counterclaim in disguise'. ${ }^{38}$ The reason for this similarity is that both set-off and counterclaim are meant to avoid circuity of action. The outcome of a counterclaim, the order of a 'net' judgment between the parties, is also similar to that of a set-off. In fact, even the motives of defendants raising a counterclaim are similar to those of raising a set-off. A counterclaim will often be

31 Derham, supra n. 1, at pp. 20 et seq.; Wood, supra n. 14, No. 43-4; see also Hoffman LJ in The 'New' Vanguard', supra n. 27, at p. 195.

32 See The 'New Vanguard', supra n. 27, at p. 200 stating that 'transaction set-off' encompasses both the common law abatement and equitable set-off.

33 See Derham, supra n. 1, at 57; Hanak v. Green [1958] 2 QB 9; The 'Kostas Melas' [1981] 1 Lloyd's Rep. 18 at 26; Federal Commerce \& Navigation Co. Ltd v. Molena Alpha Inc. [1978] 1 QB 927 at 982; for Australia see AWA Ltd v. Exicom Australia Pty Ltd [1990] NSWLR 705 at 711.

34 The Angelic Grace [1981] 1 Lloyd's Rep. 288; British Anzani (Felixstowe) Ltd v. International Marine Management (UK) Ltd [1980] 1 QB 137; National Westminster Bank plc v. Skelton [1993] 1 WLR 72 at 76; see also Henriksens Reederei A/S v. THZ Rolimpex (The Brede) [1974] QB 233; Derham, supra n. 1 at p. 71 ('... opinions which seem to indicate the contrary should not be regarded as representing the true position'); but see Poudret, supra n. 2, at p. 382, stating that 'transaction set-off' refers to set-off of claims arising out of the same contract.

35 See Derham, supra n. 1, at p. 57 on one side and Wood, supra n. 14, Nos. 4-25, 11-24, 14-56 on the other.

36 Wood, supra n. 14, No. 1-37 in fine; $c$. already Savigny, System des heutigen Römischen Rechts, Vol. 5 (1847) at p. 335.

37 See infra VIII.

38 Habscheid, 'Das schweizerische Schiedskonkordat, der Entwurf zu einem Bundesgesetz über das Internationale Privatrecht und die Internationale Schiedgsgerichtsbarkeit' in Festschrift Nagel (1987) at pp. 70, 80; cf. also Hußlein-Stich, Das UNCITRAL-Modellgesetz über die Internationale Handelsschiedsgerichtsbarkeit (1990) at p. 123. 
raised merely because certain prerequisites for a set-off under the applicable law are not fulfilled. Also, the counterclaim is frequently used as a delaying tactic in international economic arbitration ${ }^{39}$ or as a retaliatory device. ${ }^{40}$ Sometimes, the defendant even misuses an ostensible counterclaim as a disguised response to the claim. ${ }^{41}$

In some jurisdictions, counterclaim and set-off are closely intertwined. This applies, e.g., to the 'compensation judiciaire' of French law. This institution is a procedural means provided for in Article 70 of the French Nouveau Code de Procédure Civil. A claim which the debtor raises in a counterclaim ('demande reconventionnelle en compensation') because the requirements of the 'compensation légale' under Articles 1289 et seq. of the French Code Civil are not met, is transformed by the judge into a claim which is eligible for set-off against the claim raised by the claimant. ${ }^{42}$ Contrary to the 'compensation légale', the judge enjoys discretion to grant the compensation. Usually, he will declare the set-off if he considers it necessary for the protection of the respondent. ${ }^{43}$ Swiss counsel from French-speaking cantons sometimes introduce this procedural notion of set-off in international arbitrations when they follow the approach known from their Cantonal procedural law and name their set-off defence, irrespective of the applicable law, 'claim for set-off.

It was due to this intrinsic functional similarity of both institutions that the drafters of the UNCITRAL Model Law assumed that a respondent, raising the plea of set-off, has to state the facts supporting this defence in the same manner as he would have to support a counterclaim. ${ }^{44}$ The same applies under Articles 19(4), 18(2) of the UNCITRAL Arbitration Rules and Article 42(c) of the WIPO Arbitration Rules.

In spite of these similarities, set-off and counterclaim have to be distinguished sharply from each other. ${ }^{45}$ The European Court of Justice has emphasized this distinction in a recent decision concerning the interpretation of Article 6 No. 3 of

39) Szasz, 'Arbitration Rules and Practices of Institutions' in (1991) ICCA Congress ser. No. 5 (ed. van den Berg) at pp. 38,42 .

40) Ulmer, 'Winning the Opening Stages of an ICC-Arbitration' in (1991) 8 J. Int'l Arb. at pp. 33, 42, pointing out that in complex construction cases it is almost always possible for the respondent to state some sort of counterclaim ("Many defendants insist on filing a counterclaim based on the cliché assumptions that: "we have to have something to bargain away" and the arbitrators always "cut the baby in half".').

41 Fletcher, 'Unrealised Expectations - The Root of Procedural Confusion in International Arbitrations' in (1988) 4 Arbitration International 1 at pp. $40,42$.

42 See Terré, Siruler and Lequette, supra n. 19, at p. 986: 'Le role du juge est alors de parfaire les caractères de cette créance, afin de rendre la compensation possible.'

43 See Bénabent, Droit Civil, Les Obligations (1995, 5th ed.) at p. 423; cf. generally for the origin of set-off in the notion of good faith supra II(b).

44 See UN Doc. A/CN.9/264, Art. 23, para. 7 in fine.

4.5 But see Hußlein-Stich, supra n. 38, at p. 122, speaking of 'set-off through counterclaim' ('Aufrechnung durch Widerklage'). 
the Brussels Judgments Convention. ${ }^{46}$ A counterclaim ('demande reconventionelle', 'Widerklage') is a procedural instrument to raise an independent substantive claim, i.e. a means for the respondent to take the initiative and attack the claimant in order to obtain a separate judgment. ${ }^{47}$ Thus, a successful counterclaim may result in two judgments, i.e. a judgment for the claimant on his claim and a judgment for the respondent on his counterclaim. ${ }^{48}$ It is for this reason that the UNCITRAL Model Law provides in Article 2(f) that the provisions of the Law apply mutatis mutandis to a counterclaim. ${ }^{49}$ Thus, the respondent, who intends to raise a counterclaim, is subject to the general rules relating to the presentation and amendment viz. supplementation of the claim.

An important distinction also has to be drawn between set-off and counterclaim when the claim is withdrawn. In this case, the tribunal remains competent for the decision on the counterclaim ${ }^{50}$ which takes on a life of its own. ${ }^{51}$

Set-off, whether of a substantive or a procedural quality, is not a device to attack but a mere defence of the respondent against the claimant's claim. ${ }^{52}$ It can be used only 'as a shield, not as a sword'. ${ }^{53} \mathrm{~A}$ set-off may also be declared by the claimant as a defence against a counterclaim raised by the respondent, ${ }^{54}$ provided that the tribunal has ascertained that the respondent has in fact raised a counterclaim and not merely a set-off. Contrary to a counterclaim, the respondent can recover nothing for himself. The arbitrator, therefore, need not make the set-off the subject of a separate decision in his award. ${ }^{55}$ The viability of this defence always remains dependent on the main claim throughout the life of the arbitration. If, therefore, the arbitral tribunal determines during the arbitral proceedings that the

Danværn Production A/S v. Schuhfabriken Otterbeck GmbH \& Co., C-341/93, in (1997) Praxis des Internationalen Privat- und Verfahrensrechts (IPRax) at p. 114; see also Philip, 'Set-offs and Counterclaims under the Brussels Judgments Convention', in (1997) IPRax at pp. 97 et seq.; cf. also Coester-Waltjen, 'Die Aufrechnung im internationalen Zivilprozeßrecht' in Festschrift Lüke (1983) at pp. 35, 46.

47 See Cockburn CJ in Stooke v. Taylor [1880] 5 QB 569 at 576: '... the most striking difference is that the counterclaim operates not merely as a defence, as does the set-off, but in all respects as an independent action by the defendant against the plaintiff. To the extent to which the damages accruing to the defendant on the counterclaim may be in excess of those accruing to the plaintiff on his claim, the defendant becomes entitled to judgement ...'; $c$. also Derham, supra n. 1, at p. 2; Söderlund, 'Verfahrensfragen im Rahmen der internationalen Schiedsgerichtsbarkeit' in (1997) Betriebs-Berater, Supplement No. 13, at pp. 18, 24. Derham, ibid.; see also ICC Award No. 5946, reprinted in Collection of ICC Arbitral Awards (eds Arnaldez, Derains and Hascher) (1997) at pp. 46, 65: 'Accordingly, the respondent's claim for set-off must be denied. This results in the Sole Arbitrator's obligation of awarding separately to the claimant the purchase price and to the respondent the damages for lost profit.' cf. UN Doc. A/CN.9/246, para. 196; A/CN.9/264, Art. 16, B., para. 5, n. 54.

50 Provided that the counterclaim is within the scope of the arbitration agreement, see for this problem that applies to both set-off and counterclaim infra $\mathrm{V}(\mathrm{a})(\mathrm{i})$.

51 Sanders, 'Commentaries on UNCITRAL Arbitration Rules' in (1997) Yearbook Commercial Arbitration at p. 205; cf. also Iran-US Claims Tribunal, Computer Sciences Corporation v. The Government of the Islamic Republic of Iran [1986] 10 Iran-US CTR 269 at 312.

52 See Hoffman IJ in Stein v. Blake [1995] 2 All ER 961 at 966, stating that set-off under the Statutes 'can be invoked only by filing of a defence in an action'.

53 Stooke v. Taylor [1880] 5 QB 569 at 575; see also European Court of Justice, supra n. 46, ibid. and Philip, supra n. 46 , ibid.

54 See ICC Award No. 3540, supra n. 1, at pp. 111 et seq.

55 See Mustill and Boyd, supra n. 11, at p. 131. 
claimant's claim is outside the scope of the arbitration agreement, there is no setoff. ${ }^{56}$ The claimant may proceed to pursue his claim before the courts which then have to decide whether a set-off with a cross-claim that is subject to an arbitration agreement may be admitted. ${ }^{57}$ Also, the cross-claim on which the set-off is based is involved in the arbitration only insofar as it does not exceed the amount of the main claim ${ }^{58}$ while the counterclaim, being a claim of its own, is not subject to such a limitation. ${ }^{59}$

\section{APPLICABLE IAW}

Not infrequently, the various laws that may have a bearing on the determination of the admissibility of set-off in international economic arbitration are insufficiently distinguished from each other. Sometimes, the reason for this negligent treatment of the conflict of laws problem is caused by a confusion about what 'admissibility of the set-off' really means. It may refer to the viability of the defence itself, which has to be determined under its own applicable law (b). However, this question may only be dealt with by the arbitrators once the procedural admissibility of the defence has been ascertained. ${ }^{60}$ Thus, the first issue is whether the party invoking the set-off is allowed to introduce this defence into the arbitral proceedings (a). If this question cannot be answered in the affirmative, there is no room for an investigation into the justification of the set-off defence under the law applicable to it.

\section{(a) The Law Applicable to the Procedural Admissibility of the Set-Off Defence}

The procedural admissibility of the set-off defence may be determined from two different angles.

The first angle finds a parallel in proceedings before domestic courts where the procedural admissibility of the set-off is governed by the 'lex fori' ${ }^{61}$ In the absence of a lex fori of international arbitral tribunals, the arbitrators have to decide this issue with reference to the applicable arbitration law, the 'lex loci arbitri' ${ }^{62}$ Since most arbitration laws today follow the territorial theory, this will almost always be the arbitration law in force at the seat of the arbitration and the legal doctrine developed in that jurisdiction. If and to the extent that this law leaves room for

\footnotetext{
Mustill and Boyd, supra n. 11, at p. 130.

See infra VII.

58 See Baker and Davis, 'Arbitral Proceedings under the UNCITRAL Rules - The Experience of The IranUS Claims Tribunal' in (1989) 23 G. Wash. J Int'l L \& Ec. at p. 286; cf. also Savigny, supra n. 36, at p. 336.

59 See Savigny, supra n. 36 , at p. 335.

60 See ICC Award No. 5971 in (1995) 13 ASA Bulletin at pp. 728, 729 et seq.

61 See German Federal Supreme Court (BGH) in (1979) Neue Juristische Wochenschrift at p. 2477; Reithmann and Martiny, Internationales Vertragsrecht (1996,5th ed.) No. 284; Honsell, Vogt, Schnyder and Dasser, Internationales Privatrecht (1996) Art. 148, No. 15.

62 See Honsell, Vogt, Schnyder and Wenger, Internationales Privatrecht (1996) Art. 186, No. 23.
} 
party autonomy, the arbitral tribunal will also have to look at the agreements of the parties, including arbitration rules which were referred to in the arbitration clause. ${ }^{63}$

The second angle relates to the scope and interpretation of the arbitration agreement. In certain cases to be discussed below, ${ }^{64}$ the admissibility of the set-off may depend on the question whether the parties have expressly or impliedly extended the scope of the arbitration agreement to the cross-claim on which the set-off is based. This agreement may have been made already in the initial contract or later during the arbitration proceedings. In all of these cases the arbitrators have to determine the scope of the arbitration agreement according to the law applicable to it. ${ }^{65}$ If the parties have not made a choice of law relating to the arbitration agreement, Article 178(2) of the Swiss Statute on Private International Law (SPIL) refers the arbitrator to the law governing the subject matter of the dispute or to Swiss law. Article V(1)(a) of the New York Convention also refers to the law of the seat of the arbitration if the parties have not made a choice of law. It is often overlooked that it is not only the arbitration agreement covering the claim but also the (possibly different) arbitration agreement covering the cross-claim and the law applicable to it which has a decisive influence on the determination of the admissibility of the set-off defence. ${ }^{66}$

Article 178(2) of the Swiss SPIL provides an important indication for the general thrust of the interpretation of the arbitration agreement. The provision reflects the general principle of 'in favorem validitatis', which strives to uphold the validity of the arbitration agreement as much as possible, thereby preserving the overall efficiency of the arbitral process. ${ }^{67}$

\section{(b) The Law Governing the Determination of the Merits of the Set-Off Defence}

Once the procedural admissibility of the set-off has been affirmed by the arbitrators, they may proceed to determine the merits of the plea, including the existence of the cross-claim. In the majority of cases, international arbitrators will not follow a transnational approach ${ }^{68}$ but will determine the applicable law

63 Honsell, Vogt, Schnyder and Wenger, ibid.

64 See infra V(a)(ii) and (b)(ii).

65 See Poudret, supra n. 2, at p, 379; Schlosser, supra n. 19, No. 399, cf. also Heini, Keller, Siehr, Vischer, Volken and Vischer, Kommentar zum Bundesgesetz über das Internationale Privatrecht (1993) Art. 182, No. 13.

66) See infra V(b)(iii).

67 See Berger, International Economic Arbitration (1993) at pp. 156 et seq.

68 The arbitrators in the ICC Award No. 3540, supra n. 1, acknowledged that set-off belongs to the realm of transnational law; cf. also ICC Award No. 5971 in (1995) 13 ASA Bulletin at pp. 728, 740 et seq., where the arbitrators detected common principles of set-off in French, Yugoslav and Swiss law; see also Mayer, 'Le principe de bonne foi devant les arbitres du commerce international' in Études de droit international en l'honneur de Pierre Lalive (1993) at pp. 543, 554; Ripert, 'Les règles du droit civil applicables aux rapports internationaux' (Contribution à l'étude des principes généraux du droit visés au Statut de la Cour Permanente de Justice Internationale) in (1993-II) Recueil des Cours at pp. 569, 641 et seq.; Berger, Formalisierte oder schleichende Kodifizierung des transnationalen Wirtschaftsrechts (1996) at p. 229; a general principle of set-off is also alleged to exist under the UN Sales Convention (CISG), see Magnus, 'Die 
according to classical conflict of laws principles. The question of the law applicable to a set-off defence is one of the most discussed issues of conflict of laws. According to the prevailing opinion in European conflict of laws doctrine, set-off is governed by the law of the claim which the debtor asserts has been discharged by the set-off. ${ }^{69}$ The reasoning behind this rule is that the issue of whether a party is discharged from its obligation is governed by the proper law of the contract out of which this obligation arises. ${ }^{70}$ This view is confirmed by Article 148(2) of the Swiss SPIL which provides that the law applicable to set-off is 'that governing the right against which set-off is asserted'. Similarly, Article 10(1)(d) of the Rome Convention on the Law Applicable to Contractual Obligations of 19 June 1980 provides that the proper law of the contract also applies to the various ways of extinguishing obligations .... It is generally agreed that this provision also applies to set-off. ${ }^{71}$ The problem with this conflict of laws approach is that it takes the perspective of the party that declares the set-off. In those rare cases where claim and cross-claim are governed by different laws, the question of the validity of the plea of set-off may depend upon who raises it first. ${ }^{72}$ This rule applies even in those cases where the law so determined qualifies set-off as an element of procedural law. ${ }^{73}$

In France ${ }^{74}$ and Belgium, ${ }^{75}$ a different approach is favoured to determine the law applicable to the 'compensation légale'. According to the 'cumulative theory', the set-off is justified only if the laws applicable both to the debtor's and to the creditor's claim declare set-off admissible. Obviously, this view is a result of the $e x$ lege effect of the 'compensation légale', which does not require a declaration by

cont.

allgemeinen Grundsätze im UN Kaufrecht' in (1995) RabelsZ at pp. 469, 485; Piltz, Internationales Kaufrecht (1993) at p. 252.

69 cf. the decisions of the German Federal Supreme Court BGHZ 38, 254, 256; BGH in (1973) Außenwirtschaftsdienst des Betriebs-Beraters at p. 167; Kegel, Internationales Privatrecht (1995, 7th ed.) $\S 18 \mathrm{~V}$; Reithmann and Martiny, Internationales Vertragsrecht, supra n. 61, No. 284; Ulmer, Die Aufrechnung von Heimwährungs- und Fremdwährungsforderungen (1931) at pp. 21 et seq.; Berger, supra n. 1, at pp. 448 et seq.; see for Swiss law the case law of the Swiss Federal Tribunal BGE 63 II 383, 384; 77 II 189, 190; 81 II 175, 177; Schnitzer, Handbuch des Internationalen Privatrechts (1957, 4th ed.) No. 108 and Article 148(2) of the Swiss Federal Act on Private International Law; for Dutch law see Hof Amsterdam of '16 February 1989 in (1989) NIPR at p. 250; Bertrams, 'Set-Off in Private International Law', in Comparability and Evaluation (eds Boele-Woelki, Grosheide, Hondius and Steenhoff) (1994) at pp. 153, 159 et seq.; for English law MacFarlane v. Norris [1862] 2 B\&S 783; Rouquette v. Overmann [1875] 10 QB 525 at 540 et seq.; Dicey and Morris, The Conflict of Laws (1993, 12th ed.) at p. 182.

70 Wood, supra n. 14, No. 23-11; Berger, supra n. 1, at pp. 448 et seq.

71 See Kropholler, Internationales Privatrecht (1994, 2nd ed.) at p. 426 for the identical provision of Article 32(1) No. 4 of the Introductory Law to the German Civil Code (Einführungsgesetz zum Bürgerlichen Gesetzbuch, EGBGB).

72 cf. Berger, supra n. 1, at p. 449; Eujen, supra n. 26, at p. 118.

73 See Kropholler, supra n. 71 , at p. 427.

74 The doctrine was first introduced by Brocher, Cours de droit international privé, Vol. 2 (1882) at pp. 120 et seq.; $c f$. also Battifol and Lagarde, Traité élémentaire de droit international privé, Vol. 2, No. 614; Mayer, Droit international privé (1973) at 585; Eujen, supra n. 26, at p. 100.

75 See Delierneux, 'Rapport de synthèse et conclusion générale' in (1994) Revue de la Banque at pp. 174, 17.5 . 
one of the parties. As a consequence of this ex lege effect the 'compensation légale' is of a neutral character ${ }^{76}$ in that it does not serve the interests of one or other party. ${ }^{77}$ Frequently, this cumulative approach will also be followed by international arbitrators. They frequently refer to the conflict of laws principles of all jurisdictions concerned (the law of the claimant, the law of the respondent and the law of the seat of the arbitration) in order to attach more persuasiveness to their decision on the law applicable to the merits. ${ }^{78}$ Thus, the approach is not dictated by law but applied for practical purposes.

\section{PROCEDURAL ADMISSIBILITY OF SET-OFF}

In determining the procedural admissibility of a set-off defence, international arbitrators may be confronted with two different scenarios. In the first scenario, the cross-claim on which the set-off is based is subject to the same arbitration agreement (a). In the second scenario, the cross-claim is subject to a different arbitration clause, a jurisdiction clause or is not governed by any forum selection clause (b).

\section{(a) Cross-claim Not Subject to a Jurisdiction or Different Arbitration Clause}

\section{(i) The principle}

The basic procedural prerequisite ${ }^{79}$ of set-off in this scenario is derived from the consensual character of arbitration: the cross-claim has to be within the scope of the arbitration agreement. ${ }^{80}$ This is the most commonly encountered form of setoff in practice. ${ }^{81}$ It is for this reason that Article 19(3) of the UNCITRAL Arbitration Rules provides that the respondent may rely on 'a claim arising out of the same contract for the purpose of a set-off'. The UNCITRAL Model Law does not contain such a provision. However, it was made clear during the deliberations of the Working Group that this restriction to the scope of the arbitration agreement 'is self-evident in view of the fact that the jurisdiction of the arbitral tribunal is based on, and given within the limits of, that agreement' ${ }^{\prime 2}$ This basic

76 See Berger, supra n. 1, at p. 70.

77 Eujen, supra n. 26, at p, 110; Graf, Die Verrechnung im internationalen Privatrecht (1951) at p. 72.

78 See Craig, Park and Paulsson, International Chamber of Commerce Arbitration (1990, 2nd ed.) at p. 79; see also Sandrock, 'Welches Kollisionsrecht hat ein Internationales Schiedsgericht anzuwenden?' in (1992) Recht der Internationalen Wirtschaft at pp. 785, 794.

79 The question of the procedural admissibility of the set-off is independent of its characterization as an institute of procedural (as in Anglo-American law) or substantive law (as in Continental Europe), see E. Bucher, supra n. 21, at p. 710.

80 Lebedev, 'Conduct of Arbitral Proceedings' in (1984) Rassegna Dell' Arbitrato at pp. 41, 44; Söderlund, supra n. 47, at p. 24; Rüede and Hadenfeldt, Schweizerisches Schiedsgerichtsrecht (1980) at p. 251; Mustill and Boyd, supra n. 11, at p. 131; UN Doc. A/CN.9/264, Article 23, para. 8 in fine.

81 See Mustill and Boyd, supra n. 11, at p. 131 .

82 UN Doc. A/CN.9/264, Article 23, paras. 5 and 8; cf. also Hußlein-Stich, supra n. 38, at p. 123. 
rule also prevents the respondent from enlarging the arbitrators' jurisdiction unilaterally simply by raising the defence of set-off.

Consequently, the set-off has to involve a claim concerning a 'dispute which has arisen out of or in connection with the contract' that contains the arbitration agreement. This wording covers not only contractual claims. ${ }^{83}$ Thus, from this procedural standpoint, ${ }^{84}$ the cross-claim can also be of a tortious nature. Under these circumstances, the 'dispute' required by the traditional wording of the arbitration agreement exists even in those cases where the claimant's claim is undisputed but a set-off is raised by the respondent as a true defence, e.g. as an equitable or 'transaction' set-off under English law. ${ }^{85}$ It is for this reason that if the claimant brings an action before a domestic court, the respondent who raises a setoff based on a cross-claim that falls within the scope of the arbitration agreement and constitutes a true defence, may apply to the court and have the legal proceedings stayed (section 9(1) of the English 1996 Arbitration Act), rejected as inadmissible (section 1032(1) of the new German Arbitration Law) or referred to arbitration (Article 8(1) UNCITRAL Model Law). ${ }^{86}$

If the arbitration agreement does not cover the cross-claim, the parties may agree to extend the arbitration agreement. ${ }^{87}$ This procedure was suggested by the arbitral tribunal but not followed by the parties in a partial award relating to the famous SOFIDIF case. ${ }^{88}$ An agreement to extend the scope of the arbitration agreement may be effected impliedly if the claimant does not object to the setting off of a cross-claim that lies outside the scope of the arbitration agreement. ${ }^{89}$ However, it is most often overlooked that the claimant's procedural conduct may

8. See generally Berger, supra n. 67, at p. 124; cf. also the new wording of the ICC Standard Arbitration Clause (ICC Publ. No. 581, at p. 8) referring to disputes arising 'out of or in connection' with the contract instead of just 'in connection'.

84 Another question is whether the substantive law applicable to the set-off accepts such cross-claims.

85 See Mustill and Boyd, supra n. 11, at p. 130, hinting at the fact that this principle does not apply in those cases where under English law, the set-off operates not as a defence of substantive law but as a mere procedural device, see for this differentiation under English law supra II(c); $c f$. also Derham, supra n. 1, at p. 3.

${ }^{6}$ See for English law Federal Commerce \& Navigation Co. Ltd v. Molena Alpha Inc. [1978] 1 QB 927 at 928; Derham, supra n. 1, at pp. 3 et seq.

87 Rüede and Hadenfeldt, supra n. 80, at p. 253 (set-off plea as offer to extend the arbitration agreement); $c f$. also the critical comment by Schlosser, 'Notwendige Reformen des deutschen Rechts der Schiedsgerichtsbarkeit' in (1987) Zeitschrift für Wirtschaftsrecht und Insolvenzpraxis at p. 497, who regards this as a constructive device which forces the respondent to raise the plea of set-off 'at the cost' of the acceptance of the tribunal's competence. The primacy of party autonomy and the protective function of the arbitration agreement require the extension of the arbitration agreement to the set-off claim which is not covered by the initial agreement.

88 ICC Interim Award No. 2, Case No. 5124 (unpublished), at p. 12: '[Adjudicating the set-off in the present arbitration] depends on whether the parties are prepared to simplify proceedings and to enter into an agreement to lextend the scope of the arbitration agreement to the cross-claim]. The Tribunal can only express its willingness to cooperate if this would be the case'; $c f$. generally for the history of this case Gaillard, 'L'Affaire SOFIDIF ou Les Difficultés de L'Arbitrage Multipartite' in (1987) Rev. de l'Arb at pp. 275 et seq.; see also infra (b)(i).

89 Aden, Internationale Handelsschiedsgerichtsbarkeit (1988) at p. 86; see also van Houtte, 'Conduct of Arbitral Proceedings' in Essays on International Commercial Arbitration (ed. Sarcevic) (1989) at pp. 113, 121. 
have such an important effect on the plane of substantive law. The parties may have agreed on contractual set-off, which is permissible under almost all laws of the world. ${ }^{90}$

\section{(ii) Cross-claims arising out of closely related contracts}

There are precedents in international case law where the respondent has based his set-off defence on a cross-claim that arose out of a contract closely related to the one in dispute.

In an award rendered under the auspices of the Court of Arbitration at the Chamber of Commerce and Industry in Sofia in 1980, ${ }^{91}$ the arbitrators had to decide on a set-off plea that was based on a claim arising out of a loan agreement. This agreement had been concluded between the parties in order to finance the purchase under the sales contract which formed the subject of the dispute. The loan agreement did not contain any forum selection clause. The arbitrators did not hesitate to admit the set-off. They reasoned that 'the loan agreement could be regarded as a clause of the sales contract, albeit embodied by [sic] a separate document'. ${ }^{92}$ The tribunal found further support in previous decisions of the Court of Appeals of Nuremberg and the German Federal Supreme Court rendered with respect to the contracts in dispute. Both courts had acknowledged that due to the close link between the sales contract and the loan agreement, the arbitration agreement contained in the former extended to disputes arising out of the latter as well. ${ }^{93}$

It is clear from the reasoning of the arbitrators that the extremely close connection between the contracts made it easy for the tribunal to confirm the admissibility of the set-off. Not infrequently, the question arises in arbitral practice whether an arbitration agreement contained in one contract extends to related contracts. ${ }^{94}$ No general solution can be given for these cases. The answer always depends on the circumstances of the case, especially on the wording of the arbitration agreement in the main contract and on the attitude of the applicable law towards the interpretation of arbitration agreements. Thus, the model arbitration clause of the Netherlands Arbitration Institute (NAI) refers to arbitration 'all disputes arising in connection with the present contract and further contracts resulting thereof'. This wording provides a perfect example for an extension of the arbitration agreement to related contracts even though the question remains when a contract 'results' from the main contract. ${ }^{95}$ In case of the usual standard

90 Wood, supra n. 14, No. 24-43: 'Contractual set-off appears to be universally allowed where it would not otherwise be available'; see also Berger, supra n. 1, at pp. 84 et seq.

91 Award of 1 October 1980 in (1987) Yearbook Commercial Arbitration at p. 84.

92 ibid.

93 ibid.

94 See, e.g. the ICSID case SOABI v. La République du Sénégal in (1991) ICSID Review at pp. 124, 144; Nova (Jersey) Knit Ltd v. Kammgam Spinnerei GmbH in 11977] 1 Lloyd's Rep. 163; Craig, Park and Paulsson, supra n. 78, at pp. 100 et seq.; Berger, supra n. 67, at p. 123.

95 See Craig, Park and Paulsson, ibid., at p. 110; Berger, supra n. 67, at p, 123. 
arbitration clause covering all disputes 'arising out of or in connection with the present contract', the answer depends on whether the close link between the main contract and the ancillary contract out of which the cross-claim arises justifies the assumption that the dispute over the cross-claim did in fact arise 'in connection' with the main contract that forms the subject of the arbitration. In England, the courts have given a surprisingly restrictive interpretation to this terminology. ${ }^{96} \mathrm{~A}$ close economic link justifying an extension of the arbitration agreement in exceptional cases may be assumed if a guarantee that does not contain an arbitration agreement serves as security for the performance of a main contract containing an arbitration clause. ${ }^{97}$ In the ICC Award No. 5971,98 the arbitrators referred to the award of the Sofia Chamber of Commerce as support for admitting a set-off based on a cross-claim arising from an 'equipment purchase contract'. In the eyes of the arbitrators, this contract was so closely related to the joint venture contract in dispute that both were characterized by the arbitrators as an 'ensemble économique' and 'ensemble légal' in the sense that the purchase contract contained the details of the sales transactions that were already envisaged in the joint venture agreement. There was, however, one important difference between this case and the award rendered by the tribunal in Sofia. In the ICC case, the purchase contract contained another arbitration clause referring to the rules of a different arbitral institution. As will be seen below, ${ }^{99}$ this adds a particular procedural coloration to the problem which prevents a solution that is based solely on the interpretation of the arbitration agreement of the main contract.

\section{(iii) Possible decisions by the tribunal}

If the set-off is the only defence raised by respondent and the cross-claim is disputed and substantially lower than the main claim, the arbitral tribunal, in order to preserve the claimant's cash-flow, may decide, in a partial award, that such sum is payable to claimant as proves not to be in dispute after taking into account the extent of the cross-claim. ${ }^{100}$ This procedure was discussed extensively in the Interim Award relating to the SOFIDIF case and the ensuing decisions of the Swiss courts. ${ }^{101}$ According to English case law, a partial award on parts of the amount claimed can also be rendered if the party exercising its right of set-off cannot convince the tribunal that it has reasonable grounds for exercising this right and that it is acting in good faith. ${ }^{102}$ Since good faith is a general principle of law

\footnotetext{
Mustill and Boyd, supra n. 11, at p. 87.

See Craig, Park and Paulsson, supra n. 78, at p. 101.

98 ICC Award No. 5971 in (1995) 13 ASA Bulletin at pp. 728 et seq.

99 See infra (b) (iii).

${ }^{100}$ See SL Sethia Liners Ltd v. Naviagro Maritime Corporation (The 'Kostas Melas') in [1981] Lloyd's Rep. 18 at 26; Derham, supra n. 1, at p. 4, n. 16.

${ }^{101}$ ICC Interim Award No. 2, ICC Arbitration No. 5124 (unpublished), at p. 10; decision of the Swiss Federal Tribunal of 17 May 1990, at p. 11.

${ }^{102}$ The 'Kostas Melas', ibid., at p. 27; Industriebeteiligungs- \& Handelsgesellschaft v. Malaysian International Shipping Corporation Berhead (The 'Bunga Melawis') [1991] Lloyd's Rep. 271 at 273.
} 
limiting the exercise of a party's rights, ${ }^{103}$ this approach could be taken by any arbitral tribunal provided that it is clear beyond doubt that the set-off violates good faith, e.g. is brought merely to delay and obstruct the proceedings. If, on the other hand, the cross-claim is substantially higher than the claim, an award in which the tribunal reserves its decision on the set-off for the final award is provisional and not enforceable. ${ }^{104}$

Finally, if the success of the set-off is doubtful and requires complex and timeconsuming legal and factual investigations with respect to the cross-claim, the arbitral tribunal may take a pragmatic approach and render an interim award in favour of the claimant, requiring him to pay security in the amount of the crossclaim until the decision on the set-off has been made. ${ }^{105}$

\section{(iv) The special case of late set-off}

Sometimes, international arbitrators have to cope with set-offs that are raised late in the arbitration. Sometimes, the set-off may be misused to delay or obstruct the proceedings. ${ }^{106}$ Here, the same principles apply that a tribunal has to take into account when evaluating the admissibility of a counterclaim. This parallel was acknowledged by the UNCITRAL Working Group during the deliberations of the Model Law. ${ }^{107}$ It is also reflected in Article 44 of the WIPO Arbitration Rules.

Under most modern arbitration rules the tribunal may admit a later counterclaim in exceptional cases. Article 26 of the International Arbitration Rules of the Zurich Chamber of Commerce always requires the consent of the claimant which will rarely be obtainable by the respondent.

When deciding on the admissibility of a plea of set-off, the tribunal has to take into consideration the procedural practicability of the simultaneous adjudication of claim and cross-claim, especially the delay of the proceedings and the procedural disadvantages for the claimant. ${ }^{108}$ Thus, the tribunal in ICC arbitration No. 3540, after having ascertained the transnational requirements of set-off, ${ }^{109}$ added the statement that 'it does not appear to the arbitral tribunal ... that the claim of $\mathrm{A}$

\footnotetext{
${ }^{103}$ See Berger, supra n. 67, at pp. 217 et seq.

104 See Henn, Schiedsverfahrensrecht $(1991,2 \mathrm{nd}$ ed.) at p. 178.

105 See ICC Award No. 3540, supra n. 1, at pp. 113 et seq. (where the set-off was declared by the claimant as defence against the respondent's counterclaim); $c f$. the Note to this award by Derains, reprinted in Collection of ICC Arbitral Awards 1974-1985, 1990 (eds Jarvin and Derains) at pp. 406, 412 ('One understands that a party does not want to pay to his adversary a sum which he does not contest is due to it if, at the same time, the exact amount of a claim which it purports to have against the latter has not yet been determined. In fact, an anticipatory payment would deprive that party of the security in form of a set-off. The arbitral tribunal lin the ICC Award No. 3540l, aware of this difficulty, has adopted a practical approach in that it has decided that this payment may not be made unless accompanied by a guaranty.'); Reiner, supra n. 2, at p. 124; cf. also Derham, supra n. 1, at p. 4, n. 16.

106 See Reiner, supra n. 2, at p. 116; Poudret, supra n. 2, at p. 361.

107 See UN Doc. A/CN.9/264, Art. 23, para. 8 in fine.

108 See Holtzmann, 'Some Lessons of the Iran-US Claims Tribunal' in (1987) Private Investors Abroad at pp. 16-1, 16-20 et seq.; Baker and Davis, supra n. 58, at pp. 287 et seq. for the case law of the Iran-US Claims Tribunal.

${ }^{109}$ See supra n. 68.
} 
[the party raising the plea of set-off] against $B$ appears to be a purely dilatory means and is, prima facie, totally deprived of any foundation; consequently, the tribunal may in the course of the proceedings, directly proceed to determine the net sum of the claim'. ${ }^{110}$ If the delay in raising the plea of set-off is not excused by the respondent, the tribunal may refuse to deal with the late set-off unless this refusal might be considered as a violation of the respondent's right to be heard or his right to equal treatment. There will usually be no violation of such basic procedural rights if the respondent introduces the set-off shortly before, during or even after the oral hearing. ${ }^{111}$ The further the proceedings have advanced the higher are the standards for the admissibility of a late set-off. ${ }^{112}$ However, the tribunal's decision always has to be viewed against the idea of procedural economy, which is the guiding principle for both institutional and ad hoc arbitrations. ${ }^{113}$ Consequently, the respondent has a chance to have a late set-off admitted if the tribunal does not have to evaluate new facts and evidence to decide on it.

\section{(b) Cross-claim Subject to a Jurisdiction or Different Arbitration Clause}

In the second procedural scenario, the cross-claim is subject to a jurisdiction clause or a different arbitration clause. In this scenario, the tribunal has to decide whether it has jurisdiction to deal with the cross-claim within the arbitration irrespective of its being subject to a different jurisdiction, or whether it has to follow the respondent's argument that the arbitrators must await the outcome of the dispute over the cross-claim in that other jurisdiction before they can decide on the set-off.

\section{(i) Article 29(1) of the Swiss Concordat}

Article 29(1) of the Swiss Concordat adopts the latter approach. It provides that ' $[w]$ here one of the parties pleads a set-off on the basis of a legal relationship for which the arbitral tribunal lacks jurisdiction under the terms of the arbitration agreement, and the parties do not agree to extend the arbitration to that legal relationship, the proceedings shall be stayed, and a reasonable time shall be allowed to the party making the exception to establish it before the court having jurisdiction.'

This Article belongs to the most criticized provisions of the Concordat. It received particular attention in the SOFIDIF case. In one of the arbitrations arising out of this complex dispute and involving a claim of US $\$ 2 \mathrm{bn}$, the respondent introduced a set-off based on an alleged cross-claim of US $\$ 400 \mathrm{~m}$ that had been assigned to him and was subject to another ICC arbitration clause

\footnotetext{
${ }^{110}$ ICC Award No. 3540, supra n. 1, at p. 105.

11 See Harris International, Inc. v. The Islamic Republic of Iran et al. [1987] 17 Iran-US CTR 31 at 58; TME International, Inc. v. The Government of the Islamic republic of Iran et al. [1990] 24 Iran-US CTR 121 at 131.

112 Sanders, supra n. 51 , at p. 205 for the UNCITRAL Arbitration Rules.

${ }^{113}$ Redfern and Hunter, Law and Practice of International Commercial Arbitration (1991, 2nd ed.) at p. 242; van Houtte, supra n. 89, ibid.
} 
contained in a related contract. ${ }^{114}$ In view of the 'clear and plain language' of Article 29, the tribunal argued that 'bound by the mandatory character of Article 29, [we] cannot do anything else than stay the proceedings and allow the defendant to establish its claim before the court with jurisdiction'. The respondent was granted a time limit of five months to comply with this award and to introduce the cross-claim before the competent court. The tribunal indicated that if the respondent would not comply with the obligation imposed on him in the interim award, 'the consequence may be that the arbitral proceedings in the present case are continued without taking into account the plea of set-off'. ${ }^{115}$

In a dissenting opinion, one of the arbitrators argued that the tribunal should have first ascertained whether there is a principal debt before deciding on the stay of the proceedings. In his view, Article 29 of the Concordat could not be regarded as providing for an automatic stay. Only if and to the extent that the main claim had been established could the tribunal order a stay or - in case the cross-claim has been fully established by that time - could consider the set-off. To justify his view, the arbitrator referred to the exceptional character and limited scope of the provision, which he regarded as a means of securing that the arbitral tribunal does not transgress its jurisdiction, and to the very nature of the set-off defence which serves to extinguish the main claim, thereby presupposing that such a claim exists. The arbitrator also argued that suspension should not have been granted because set-off was excluded in the contract out of which the principal claim arose. The contract clearly stipulated for the payment of the claim in US dollars, while the respondent sought to set-off his cross-claim denominated in French francs. ${ }^{116}$ In this context, the dissenting arbitrator referred to the fact that set-off of claims in different currencies was also prohibited by the law applicable to the set-off. ${ }^{117}$ Finally, the arbitrator touched upon the 'related contracts-test' described above. ${ }^{118}$ He argued that the mere fact that there existed certain relations between the two contracts is not of itself sufficient reason to suspend the proceedings. Both arbitrations were clearly distinct as far as the composition of the arbitral tribunal, the rules applicable to the substance of the dispute and the place of arbitration were concerned. In addition he wrote, the two claims were of a different nature.

The interim award was attacked by the claimant before the Cantonal Court of

$114 \mathrm{cf}$. generally for the effect of arbitral agreements in case of assignment of claims Girsberger and Hausmaninger, 'Assignment of Rights and Agreement to Arbitrate' in (1992) 8 Arbitration International 2 at pp. 121,123 et seq.

${ }^{11.5}$ Interim Award No. 2 in ICC arbitration No. 5124 (Iran v. CEA), supra n. 88, at pp. 11 et seq.; see Blessing, in Internationales Privatrecht (eds Honsell, Vogt and Schnyder) (1996) Introduction to the Twelfth Chapter, No. 152.

116 Agreement on a certain currency in the contract may be regarded as a prohibition of set-off under certain legal systems if this agreement does not merely serve to indicate the value of the claim but fixes the currency of payment, see for Swiss law Kleiner, Internationales Devisen-Schuldrecht (1985) No. 22.71.

117 There is no uniform solution to this issue in the various legal systems; claims denominated in different currencies cannot be set off under German law while Swiss and Dutch law allow the set-off under these circumstances; see Berger, supra n. 1, at p. 253; Article 6: 129(3) Dutch Civil Code; Swiss Federal Tribunal BGE 63 II 383 et seq.

118 See supra (a) (ii). 
Geneva. The Court set aside the award for denial of justice under Article 36(d) and (f) of the Concordat. ${ }^{119}$ It stated that, prior to the suspension of the proceedings under Article 29 of the Concordat, the tribunal should have examined whether the prerequisites of set-off were fulfilled under the applicable law. Even if this question could have been answered in the affirmative by the arbitrators, the Court argued that 'in the interest of a good administration of justice' and in view of the 'flagrant disproportion' between the strong claim and the much weaker cross-claim introduced by the respondent, the arbitratorc should have suspended the proceedings only insofar as that portion of the main claim was concerned that could have been absorbed by the cross-claim. For the rest of the main claim, the tribunal should have continued the proceedings 'without delay'. This judgment was ultimately confirmed by the Swiss Federal Tribunal which pointed to the particular character of Article 29 of the Concordat, tending 'to favour abusive practices' and requiring a restrictive interpretation. ${ }^{120}$

Two important general conclusions may be derived from the history of the interim award rendered in the SOFIDIF case.

First, the complex issue of the treatment of set-off should be decided in an international arbitration only if and to the extent that it really matters, i.e. after the existence of the main claim and the admissibility of the plea of set-off under the law applicable to it ${ }^{121}$ have been ascertained by the arbitrators, including the absence of any contractual exclusion ${ }^{122}$ or legal prohibition of set-off.

Secondly, the SOFIDIF case indicates the extreme problems that arbitral practice always had in balancing the respondent's right to set off cross-claims and the need to prevent abusive practices and to foster procedural justice under Article 29 of the Concordat. Since the enactment of the 12th Chapter of the Swiss SPIL this provision no longer applies to international arbitrations having their seat in Switzerland. ${ }^{123}$ In spite of suggestions to the contrary, ${ }^{124}$ it should not be taken as a model for solutions of the set-off problem in international arbitration. The provision confuses set-off, which can be dealt with by the arbitral tribunal, and counterclaim, which, being an action of its own and not a mere defence, cannot be made subject to the competence of the arbitral tribunal without an extension of the arbitration agreement covering the claim. ${ }^{125}$ Also, experience with this provision

\footnotetext{
119 Cantonal Court of Geneva, decision of 19 December 1989.

${ }^{120}$ Swiss Federal Tribunal of 17 May 1990, BGE 116 la 154 ; Blessing, supra n. 115, ibid.; see for a list of possible ways to misuse Article 29 for delaying tactics Budin, 'La suspension dans l'arbitrage international' in (1986) Rev. de I'Arb at pp. 415, 416 et seq.

121 See supra IV(b).

122 The German Federal Supreme Court considers the payment clause 'cash on delivery' as a contractual exclusion of set-off, see BGH in (1985) Neue Juristische Wochenschrift at p. 550; however, a party may not invoke the contractual exclusion of set-off if it is bankrupt or if the cross-claim arises out of tort or out of a wilful breach of contract, see Palandt-Heinrichs, Bürgerliches Gesetzbuch (1998, 57th ed.) § 387, No. 17.

${ }^{123}$ See Poudret, supra n. 2, at pp. 377 et seq.; Berger, supra n. 67, at p. 466, n. 644 in fine.

124 See Heini, Keller, Siehr, Vischer, Volken and Vischer, supra n. 65; see also Walter, Bosch and Brönnimann, Internationale Schiedsgerichtsbarkeit in der Schweiz (1991) at p. 76.

125 See Lalive, Poudret and Reymond, Le Droit de L'Arbitrage Interne et International en Suisse (1989) Article 186, No. 8.
} 
has been very negative since it constitutes an invitation for delaying tactics based on a weak set-off defence. ${ }^{126}$ Prior to the entering into force of the SPIL parties to arbitrations in Switzerland have for this reason frequently excluded this provision. ${ }^{127}$ Hence, the ICC Second Interim Award No. 5124 has rightly been characterized as a 'prime example' for the 'unfortunate structure' of Article 29 and of the Swiss Concordat as a whole. ${ }^{128}$

After the SOFIDIF case, international arbitrators sitting in Switzerland have been very reluctant to apply Article 29. This restrictive approach is exemplified in ICC Award No. 5514. The respondent in that arbitration had argued that suspension of the proceedings under Article 29 of the Concordat would not only be required due to the 'ordre public' quality of that provision but would also be an equitable solution given that it would be 'morally and economically incomprehensible that he would have to pay the slightest sum to the claimant even though it was the creditor vis-à-vis the claimant of a much higher sum in another arbitration'. ${ }^{129}$ With this statement, the respondent indirectly referred to the historical roots of the set-off defence which lie in the "dolo agit' principle of Roman law. ${ }^{130}$ The tribunal was not impressed by this. It refused to apply Article 29, referring to the fact that suspension would 'lead to substantial delays, however advantageous it would be to facilitate a global settlement of the parties' mutual debts'.

\section{(ii) The pragmatic approach}

Contrary to the controversial solution adopted by the drafters of the Concordat, there is a growing tendency to assume that, as a rule, an international arbitral tribunal has jurisdiction to hear a set-off defence based on a cross-claim that is subject to a different arbitration agreement or jurisdiction clause. This view applies only to those set-offs that have a substantive nature, e.g. the 'Aufrechnung' or 'Verrechnung' under German or Swiss law, the 'compensation légale' under French law and the equitable or 'transaction' set-off under English law. Being a substantive defence which denies the existence of the claim, the set-off has the same quality as any other substantive defence. The tribunal should therefore be authorized to decide on all defences which are raised against the claim ('le juge de l'action est le juge de l'exception'131), and consequently also on the merits of the

\footnotetext{
${ }^{126}$ See Reiner, supra n. 2, at pp. 115 et seq.; cf. also Lalive, Poudret and Reymond, ibid., Article 29 Concordat, Nos. 1 et seq.; Habscheid, Schweizerisches Zivilprozess- und Gerichtsorganisationsrecht (1990, 2nd ed.) at p. 543; Poudret, supra n. 2, at p. 36 s ( un moyen dilatoire commode au défendeur'), stating that Article 29 constitutes an unlawful intrusion inte procedural law of other cantons, ibid., at pp. 369 et seq.

${ }^{127}$ See Paulsson, in UN Doc. A/CN.9/SR.326, para. 24.

${ }^{128}$ Blessing, supra n. 115, ibid.

129 Reprinted in Collection of ICC Arbitral Awards 1991-1995, 1997 (eds. Arnaldez, Derains, Hascher) at pp. $456,459$.

130 See supra II(a).

131 This formula is used by the Swiss Federal Tribunal and the prevailing doctrine in Switzerland, see BGE 85 II 103; Pudret, supra n. 2, at p. 364 .
} 
set-off. ${ }^{132}$ Referring the cross-claim to adjudication before the domestic court is regarded as 'depriving the set-off of its efficiency, especially when regarded as an essentially dilatory means'. ${ }^{133}$ This solution is also advocated for equitable or 'transaction' set-off raised in arbitrations having their seat in England. ${ }^{134}$ The general thrust behind this approach is of a highly practical nature. It is said to avoid 'overly formalistic' ${ }^{135}$ solutions and thereby preserve the procedural economy of the arbitration. For this very reason, the simultaneous adjudication of claim and cross-claim via the set-off defence is alleged to be in the presumed interest of the parties to the arbitration:

It is not surprising in commercial life that a party is confronted with a cross-claim that arises out of a different legal relationship and a party to an arbitration agreement must take account of this fact. In the eyes of the parties to a standard arbitration agreement, the parties' interest to have claim and cross-claim decided simultaneously and through one single instance outweighs the interest to preserve a different competence for the cross-claim. ${ }^{136}$

If the cross-claim could not be considered by the tribunal in the context of the setoff raised by the respondent, the claimant would receive an award in his favour even though a domestic court or different arbitral tribunal would subsequently (perhaps years later if the court judgment is appealed) render a judgment in favour of the respondent on his cross-claim. This latter decision indicates that, had the setoff been admitted immediately in the arbitration, the arbitral tribunal would have been able to take account of the substantive effects of the set-off, deciding that the claimant's claim has been extinguished by way of set-off with a valid cross-claim. ${ }^{137}$ The arbitral tribunal's competence to decide on the set-off would therefore avoid conflicting results with respect to the procedural (i.e. arbitral) inadmissibility of the set-off defence on one side and the effectiveness of the set-off on the plane of substantive law on the other. ${ }^{138}$ Thus, based on the presumed interests of the parties, this view establishes a presumption that international arbitral tribunals are competent to hear set-off defences that arise out of contracts which contain a different arbitration or jurisdiction clause. 'Clear indications' are required for the 'exceptional case' that the parties intended to exclude the tribunal's competence

${ }^{132}$ Reiner, supra n. 2, at p. 119; Poudret, supra n. 2, at pp. 371 and 373 (for the Concordat) and 378 (for the new SPIL); Honsell, Vogt, Schnyder and Wenger, supra n. 62, Article 186, No. 28; Baumbach, Lauterbach and Albers, Zivilprozeßordnung (1990, 48th ed.) § 1025, No. 3 C(a); Nagel, 'Gedanken über die Beschleunigung des Schiedsverfahrens' in Festschrift Firsching (1985) at pp. 191, 194 et seq.; Schwab and Walter, Schiedsgerichtsbarkeit $(1995,5$ th ed.) at pp. 22 et seq.; Rüede and Hadenfeldt, supra n. 80, at p. 253; Lalive, Poudret and Reymond, supra n. 125, Art. 186, No. 8; Perret, 'Note to Swiss Federal Tribunal of 17 May 1990' in (1990) ASA Bulletin at pp. 293, 303 et seq.; Award No. 5971 in (1995) 13 ASA Bulletin at pp. 728,736 et seq.

${ }^{133}$ Poudret, supra n. 2, at p. 372.

134 Mustill and Boyd, supra n. 11, at p. 131.

135 See ICC Award No. 5971 in (1995) 13 ASA Bulletin at pp. 728, 738.

${ }^{136}$ Honsell, Vogt, Schnyder and Wenger, supra n. 62, Article 186, No. 28 (translation by the author); but see Heini, Keller, Siehr, Vischer, Volken and Vischer, supra n. 65, Article 182, No. 13: 'The party opposing the set-off has to be protected from a surprising extension of the scope of the arbitration agreement'.

137 Reiner, supra n. 2, at pp. 114 et seq.

138 Reiner, ibid., at p. 118. 
over such cross-claims. ${ }^{139}$ Such an exceptional case is assumed if the parties to the arbitration have agreed to have their case decided in a 'fast track' procedure or if the cross-claim is subject to an arbitration agreement that refers to highly specialized arbitration rules such as those of a maritime arbitral institution. ${ }^{140}$

\section{(iii) The antinomy of conflicting forum selection clauses}

Taking a purely pragmatic approach to this problem neglects the will of the parties as expressed in the arbitration or other forum selection clause covering the crossclaim. ${ }^{141}$ In those cases where it establishes the presumption in favour of the international arbitrator's competence over cross-claims outside the tribunal's jurisdiction, it treats the set-off as if it were subject to the same arbitration agreement as the main claim. It tackles the problem at the very end of the process, the achievement of procedural economy in the arbitration in case the set-off is raised as a defence. Instead of treating the efficiency of the arbitration as a procedural value in and of itself, one should look at the very beginning, i.e. the meaning and doctrinal significance of the different forum clause covering the crossclaim. Even those who favour the simultaneous adjudication of claim and cross-claim by international arbitrators in this procedural scenario concede that there is no clear-cut rule in favour or against the admissibility of set-off. Instead, the arbitrators have to determine the will of the parties at the moment of conclusion of the arbitration agreement covering the main claim on the one side and the different forum clause covering the cross-claim on the other. ${ }^{142}$ From this ex ante perspective, both the consensual character of arbitration and the function and nature of forum selection clauses put into question the admissibility of set-off in international arbitrations. ${ }^{143}$

First, set-off is frequently the only defence available to the respondent. This means that, if the main claim is undisputed, the arbitrators have to decide only on the cross-claim which in fact was outside the scope of the arbitration agreement. ${ }^{144}$

Secondly and more importantly, the will of the parties as expressed both in the arbitration agreement that underlies the arbitration and in the jurisdiction or

${ }^{139}$ ICC Award No. 5971 in (1995) 13 ASA Bulletin at pp. 728, 739; Honsell, Vogt, Schnyder and Wenger, supra n. 62, Nos. 24, 28.

${ }^{140}$ Honsell, Vogt, Schnyder and Wenger, supra n. 62, No. 27.

141 See ICC Award No. 5971 in (1995) 13 ASA Bulletin at pp. 728, 738, stating that refusing to admit the setoff 'would deny justice to the Parties (in particular, here, to Defendants)' (emphasis added).

${ }^{142}$ Honsell, Vogt, Schnyder and Wenger, supra n. 62, Article 186, No. 28; Reiner, supra n. 2, at p. 121 with reference to Berger, Internationale Wirtschaftsschiedsgerichtsbarkeit (1992) at pp. 325 et seq. and others.

${ }^{143}$ Glossner, Bredow and Bühler, Das Schiedsgericht in der Praxis (1990, 3rd ed.) No. 129 in fine; HußleinStich, supra n. 38, at p. 123; Reithmann and Martiny, supra n. 61, No. 2498 in fine; Zöller and Geimer, Zivilprozeßordnung (1996, 20th ed.) \& 1025, No. 34; Schlosser, supra n. 19, No. 399; Wenger, 'Die internationale Schiedsgerichtsbarkeit' in (1989) Basler Juristische Mitteilungen at pp. 337, 351; A. Bucher, Die neue internationale Schiedsgerichtsbarkeit in der Schweiz (1989) No. 192; E. Bucher, in Die internationale Schiedsgerichtsbarkeit in der Schweiz (II) (ed. Böckstiegel) at pp. 138 et seq.

${ }^{144}$ Schütze, Tscherning and Wais, Handbuch des Schiedsverfahrens (1990, 2nd ed.) No. 55; see also UN Doc. A/CN.9/264, Article 23, para. 8 in fine. 
different arbitration clause that covers the cross-claim usually prevents the assumption that the tribunal is competent to hear such set-off defences.

When concluding the arbitration clause on which the arbitral proceedings are based, the parties intended to have those and only those claims decided by the arbitral tribunal which fall under the scope of the arbitration agreement. ${ }^{145}$ In the absence of a clear indication to the contrary, it is only under this condition that the parties accept the formula 'le juge de l'action est le juge de l'exception'. The principle of 'in favorem validitatis' which governs the interpretation of the arbitration agreement ${ }^{146}$ operates only within the limits set by these intentions of the parties. To extend the proceedings beyond the arbitration agreement without any indication as to a corresponding will of the parties would be against the parties' original intentions. ${ }^{147}$ This view has been confirmed by the German legislature in the travaux préparatoires of the new Arbitration Act:

If the cross-claim is not covered by the arbitration agreement, the plea of set-off may only be raised if an extension of the arbitration agreement can be assumed because the claimant does not put into question the jurisdiction of the arbitral tribunal. ${ }^{148}$

This view is in line with the case law of the Iran-US Claims Tribunal, which has repeatedly emphasized that, despite its distinct procedural nature, ${ }^{149}$ set-off has to meet the same jurisdictional standards as counterclaim, meaning that the crossclaim has to be within the jurisdiction of the Tribunal. ${ }^{150}$

The effect of this limited scope of the arbitration agreement becomes clear when looking at a case which appears to be the least problematic: an arbitration in which the respondent introduces a cross-claim arising out of another contract between the same parties containing the same arbitration clause and referring to the same arbitration rules. Even though one would be tempted to allow the set-off in this case where the parties have chosen the same jurisdiction for claim and cross-claim, this would contravene the interest of the parties as expressed in the two arbitration agreements. It would mean to reintroduce consolidation of arbitral procedures through the back-door of the set-off defence. Section 35(2) of the English 1996 Arbitration Act expresses a general principle of international arbitration law ${ }^{151}$ according to which the tribunal has no power to order consolidation of proceedings or concurrent hearings unless agreed upon by the parties. Allowing the set-off in this case might favour the party who sues first,

\footnotetext{
${ }^{145}$ See Schlosser, supra n. 19, No. 399.

146 See supra IV (a) in fine.

${ }^{147}$ Heini, Keller, Siehr, Vischer, Volken and Vischer, supra n. 65, Article 182, No. 13.

${ }^{148}$ Bericht mit einem Diskussionsentwurf (ed. Kommission zur Neuordnung des Schiedsverfahrensrechts) (1994) at p. 154; Bundestags-Drucksache No. 13/5274, reprinted in Das neue Recht der Schiedsgerichtsbarkeit/The New German Arbitration Law (ed. Berger) (1998) at p. 242 (translation by the author, emphasis added); $c f$. also Lörcher and Lörcher, Das Schiedsverfahren - national/international - nach neuem Recht (1998) at p. 56.

1.49 See supra III.

${ }^{150}$ See Computer Sciences Corp. v. Iran [1986] 10 Iran-US CTR 269 at 309; $c f$ generally Baker and Davis, The UNCITRAL Arbitration Rules in Practice (1992) at pp. 89 et seq.

1.51 See Berger, supra n. 67, at pp. 299 et seq.
} 
allowing it to determine the timing of the proceedings and to influence the general shape of the arbitral procedure. The SOFIDIF case mentioned above illustrates these problems. It involved two ICC arbitrations dealing with related contracts. It has been rightly emphasized that 'only the will of the parties expressed in the careful drafting of the arbitration agreements included in the various contracts might have avoided the difficulties which this affair illustrates'. ${ }^{152}$ This statement, made in the context of multiparty arbitration, applies equally to the problem of setoff of claims that were subject to these arbitration agreements.

The same reasoning applies to a cross-claim that is subject to a different arbitration agreement. ${ }^{153}$ It does not matter whether the parties have chosen a specialized arbitral institution for that claim or not. ${ }^{154}$ Every arbitral institution is chosen for some particular geographical, personal, technical or legal reason. Irrespective of how these reasons are assessed by outsiders, the arbitration agreement expresses the clear will of the parties to have claims arising out of that contract adjudicated under the auspices of a certain arbitral institution. The point has been made with respect to the NAI model arbitration agreement ${ }^{155}$ in cases where a 'resulting contract' provides for another manner of resolving disputes (e.g. ad hoc arbitration or another institutional clause). It has been doubted that under these circumstances, a dispute arising out of the 'resulting contact' could be arbitrated under the NAI rules. ${ }^{156}$ Why then should the respondent in the NAI arbitration be allowed to introduce the cross-claim arising out of that 'resulting contract' through a set-off defence? Party autonomy has the same principal value immaterial of whether one is dealing with an ongoing arbitration or an arbitration agreement that covers a cross-claim which the respondent would like to introduce into the arbitration via a set-off defence and which the arbitrators would like to admit for reasons of procedural economy.

Aspects of procedural economy in the ongoing arbitration may therefore take priority over the parties' will as expressed in the arbitration agreement covering the cross-claim only in those exceptional cases where the claimant clearly indicates a corresponding will. In the absence of such an intention, even the close economic link between the two contracts may not serve as an argument to supervene the will of the parties as expressed in the other arbitration agreement. ${ }^{1.57}$

When the cross-claim is not subject to another arbitration agreement but to a jurisdiction clause and the claimant opposes the tribunal's competence to hear the set-off, one has to take account not only of the parties' intentions that underlie

\footnotetext{
152 Gaillard, supra n. 88, at p. 291.

${ }^{153}$ See the Award of the Royal Ass. of the Committee of Grain Traders of 13 March 1984 in (1985) Yearbook Commercial Arbitration at pp. 79 et seq.

154 See supra n. 140.

155 See supra n. 95.

156 See Craig, Park and Paulsson, supra n. 78, at p. 110, n. 7; Berger, supra n. 67, at p. 123.

157 But see the ICC Award No. 5971 in (1995) 13 ASA Bulletin at pp. 728 et seq., where the tribunal used this argument to admit the set-off based on a cross-claim that was subject to a different institutional arbitration agreement.
} 
the arbitration agreement but also of their will as expressed in the other forum selection clause. In other words, the parties' interests expressed in the arbitration agreement do not stand alone. Rather, the vital interest of a party (i.e. the claimant) who has concluded a forum selection clause not to be taken before a foreign forum to which it has not agreed makes it clear that the tribunal's competence in these cases cannot be based on an isolated interpretation of the arbitration agreement. These interests form the basis of every forum selection clause. They outweigh any considerations of procedural economy in the arbitral proceedings. The American Supreme Court has frequently emphasized the special value of forum selection clauses in international trade. ${ }^{158}$ This protective function cannot be frustrated by a unilateral extension of the arbitrators' jurisdiction which is based on purely economical criteria. ${ }^{159}$ The claimant cannot be presumed to strive for procedural economy at all costs, i.e. even against his own clear will expressed in the forum selection clause that governs the cross-claim. The same is true if the claimant's general conditions of contract allow him to apply either to a municipal court or to an arbitral tribunal in a dispute concerning the set-off claim. ${ }^{160}$ The German Federal Supreme Court has provided the doctrinal underpinning for this view: in all of these cases the teleological interpretation of the arbitration or forum selection clauses that cover the cross-claim leads to a contractual exclusion of setoff which causes the procedural inadmissibility of the set-off irrespective of which substantive law applies to it. ${ }^{161}$

The underlying rationale of this view also sets the limits to this principle of the non-admissibility of the set-off defence in this procedural scenario.

First, set-off is admissible irrespective of a jurisdiction or different arbitration clause if the cross-claim is undisputed or has already been ascertained with 'res iudicata' effect in that other jurisdiction. In these cases the above considerations relating to the interests of the parties as expressed in the arbitration agreement and

${ }^{1.58}$ See M/S Bremen v. Zapata Off-Shore Co. [1972] 407 US 1 at 9: '[I]t would be unrealistic to think that the parties did not conduct their negotiations, including fixing the monetary terms, with the consequences of the forum clause figuring prominently in their calculations'; cf. also Scherk v. Alberto-Culver Co. [1974] 417 US 506 at 518: "The elimination of $\ldots$ uncertainties by agreeing in advance on a forum acceptable to both parties is an indispensable element in international trade, commerce and contracting.

159 But see Reiner, supra n. 2, at p. 120 who takes the opposite view and maintains that in international arbitrations in particular, set-off with cross-claims that are subject to a jurisdiction clause should be allowed.

${ }^{160} \mathrm{cf}$. the 'Award of the Hamburger freundschaftliche Arbitrage' of 17 September 1973, reprinted in Straatmann and Ulmer, Handelsrechtliche Schiedsgerichts-Praxis, (1982) B1, No. 16, which considers the set-off admissible in this case.

${ }^{161}$ cf. BGHZ 60, 85, 89 where the Court favoured an analogous application of its consistent case law under which a claim that is subject to an arbitration agreement may not be brought before a domestic court by way of a set-off; $c f$. also E. Bucher, supra n. 143, at p. 138 with reference to the case law of the Swiss Federal Tribunal; cf. also BGH in (1973) Neue Juristische Wochenschrift at p. 422; BGH in (1979) Neue Juristische Wochenschrift at pp. 2477, 2478; see also Schlosser, supra n. 19, No. 399; Schütze, Tscherning and Wais, supra n. 144, No. 55; Glossner, Bredow and Bühler, supra n. 143, No. 129; Lionnet, Handbuch der internationalen und nationalen Schiedsgerichtsbarkeit (1996) at pp. 224 et seq.; Raeschke-Kessler, Berger and Lehne, Recht und Praxis des Schiedsverfahrens (1995, 2nd ed.) No. 397; Berger, supra n. 67, at pp. 466 et seq. 
the value and the protective effect of forum selection clauses in international trade do not apply from the outset. ${ }^{162}$

A second exception applies if the claimant who objects to the procedural admissibility of the set-off during the arbitration has not reacted to the respondent's announcement of his intention to raise the plea of set-off in his response to the statement of claim. Arguing against the admissibility of the set-off on jurisdictional grounds subsequently during the arbitration would violate the general principle of 'venire contra factum proprium'. ${ }^{163}$

Finally, a third exception applies if the parties have granted the arbitrators the competence to decide on set-offs that are not subject to the arbitration agreement, thereby indicating that the competence of the arbitrators shall take priority over any other forum selection clause covering possible cross-claims. Such an agreement may be assumed if the parties have agreed that claims arising out of the main contract shall be arbitrated under the auspices of the Zurich Chamber of Commerce. Article 27 of the International Arbitration Rules of the Zurich Chamber of Commerce provides that the tribunal has jurisdiction over a set-off even if another arbitration clause or jurisdiction clause for that claim exists. Agreement on the Zurich International Arbitration Rules must therefore be regarded as an agreement of the parties to the main arbitration agreement to extend the jurisdiction of the tribunal to cross-claims that are subject to another arbitration or jurisdiction clause. ${ }^{164}$ In this case, the claimant waives in advance the protection he enjoys under these clauses.

It must be borne in mind, though, that contrary to some views described above, ${ }^{165}$ the general rule developed here is that the tribunal has no jurisdiction to hear set-off defences that are subject to jurisdiction or different arbitration clauses unless there are 'clear indications' for the 'exceptional case' that the tribunal's jurisdiction is extended by agreement of the parties to the cross-claim that would otherwise fall outside the arbitrator's competence.

\section{ARBITRAL PRACTICE}

According to the above considerations, the arbitrators will not rule on the set-off claims unless the parties agree on an extension of the arbitration agreement. The respondent may pursue his cross-claim against the claimant in the other

\footnotetext{
${ }^{162}$ Schlosser, ibid., No. 399; Schütze, Tscherning and Wais, supra n. 144, No. 55 ('To deny the tribunal's competence in this case would violate good faith'); Raeschke-Kessler, Berger and Lehne, ibid., No. 369; Berger, supra n. 67, at p. 465; Heini, Keller, Siehr, Vischer, Volken and Vischer, supra n. 65, Article 182, No. 13.

${ }_{163}$ See Berger, supra n. 142 , at p. 328 with n. 466.

164 See Honsell, Vogt, Schnyder and Wenger, supra n. 62, Article 186, No. 27; see also Article 12 of the new Lugano Arbitration Rules.

165 See supra (ii).
} 
jurisdiction. This procedure will have no effect on the arbitration ${ }^{166}$ unless there is a decision on the cross-claim assuming 'res iudicata' effect during the course of the arbitral procedure so that the arbitral tribunal may take account of this decision in its final award. ${ }^{167}$ If the respondent does not pursue his claim while the arbitration is pending, the arbitral tribunal may take the approach followed by the arbitrators in the ICC Award No. 3540.168 It may render an award in favour of the claimant, but order the claimant to pay security into an escrow account in the amount of the cross-claim if he seeks to enforce the award. At the same time, the tribunal should set a deadline for the respondent to pursue his cross-claim in the other jurisdiction in order to prevent him from blocking the enforcement process through a setoff in bad faith. Upon expiry of the deadline, the claimant should be allowed to take back the security.

The award rendered could be considered 'final' under the enforcement system of the New York Convention. This approach therefore avoids the problems connected with proposals in German legal doctrine, ${ }^{169}$ that the arbitral tribunal should render a provisional award ('Vorbehaltsschiedsspruch') according to section 302(1) of the German Code of Civil Procedure subject to the final determination of the crossclaim and set-off by the competent court or arbitral tribunal.

If the tribunal does not adopt this pragmatic approach, the substantive effect of the set-off has to be dealt with in subsequent enforcement procedures, provided that the law of the forum where enforcement is sought allows to take account of the set-off. If the claimant wants to avoid these uncertainties altogether, he may agree to have the arbitration clause extended to the cross-claim, which, of course, does not imply any concession as to the substantive viability of the set-off plea which will then be determined by the arbitrators.

\section{SET-OFF BEFORE DOMESTIC COURTS}

The basic requirement that the cross-claim on which the set-off is based must be covered by the arbitration agreement ${ }^{170}$ has a reverse effect before a domestic court if the defendant pleads a set-off based on a claim that is subject to an arbitration agreement. It is argued that the court should be competent to deal with the set-off since "it would emasculate the right of set-off if the Courts were to say to the defendant "Pay up now and arbitrate later" ". ${ }^{171}$ However, the recognition of

\footnotetext{
${ }^{166}$ See Lalive, Poudret and Reymond, supra n. 125, article 186, No. 8 in fine.

167 See supra V(b)(iii).

168 See supra n. 1.

${ }^{169}$ See Schwab and Walter, supra n. 132, at p. 24; Schütze, Tscherning and Wais, supra n. 144, No. 55; Henn, Schiedsverfahrensrecht (1991, 2nd ed.) at pp. 177 et seq.

170 See supra V(a)(i).

171 The 'New Vanguard', supra n. 27, at 200 (for equitable set-off of English law), stating that '[t]his is a difficult point on which there is no authority', ibid. at p, 199; Reiner, supra n. 2, at p. 122; Poudret, supra n. 2, at p. 373, referring to a decision of the Cantonal Court of Vaud in 1913 III Journal des Tribunaux at p. 2; Austrian Federal Supreme Court, EvBI. 1991/44.
} 
different jurisdictions for the main and the cross-claim should also apply in this situation. ${ }^{172}$ Again, the arbitration clause expresses the will of the parties to submit disputes to arbitration and to avoid every action that would contravene this intention of the parties. ${ }^{173}$ The arbitration agreement is said to contain an implied agreement to the effect that the question whether the claim exists and is valid will be determined only by the arbitral tribunal. ${ }^{174}$ The idea behind this reasoning is that no one can evade the binding force of an arbitration agreement, not even through a unilateral declaration, i.e. the plea of set-off. ${ }^{175}$ The principle of attaching maximum validity to an international arbitration agreement ("in favorem validitatis') which has become so prominent in international arbitral doctrine and practice $^{176}$ cannot be circumvented by raising claims that are subject to such an agreement before the domestic courts by virtue of a plea of set-off.

\section{COSTS OF SET-OFF}

A set-off may have repercussions on the advance of costs that have to be paid by the parties under the applicable arbitration rules. Thus, Article 30(5) of the new ICC Rules of Arbitration and its predecessor, Article 16 of the 'Internal Rules of the ICC Court of International Arbitration' (Appendix II) ${ }^{177}$ both provide that a set-off raised by one of the parties to the arbitration 'shall be taken into account in determining the advance to cover the costs of arbitration in the same way as a separate claim, insofar as it may require the Arbitral Tribunal to consider additional matters'. In practice this usually leads to an increase of the overall advance on costs. Under the old ICC Rules, ${ }^{178}$ problems arose in several arbitrations in which the respondent introduced a claim for set-off exceeding the amount of the claim, but did not pay its share of the increased advance of costs. In these cases the arbitrators were faced with the question whether they were allowed

${ }^{172}$ See the German Federal Supreme Court in BGHZ 38, 254, 258; OLG Düsseldorf in (1983) Neue Juristische Wochenschrift at p. 2149; OLG Hamm in (1983) Recht der Internationalen Wirtschaft at pp. 698, 699; BGE 63 II 133, 142; cf. also Wood, supra n. 14, No. 12-50; Reithmann and Martiny, supra n. 61, No. 2498; Berger, supra n. 67, at p. 467; Raeschke-Kessler, Berger and Lehne, supra n. 161, No. 398.

${ }_{173}$ See the reasoning of the German Federal Supreme Court in BGHZ 38, 254, 258.

${ }^{174}$ Germand Federal Supreme Court, ibid.

175 See Schütze, Tscherning and Wais, supra n. 144, No. 55.

${ }^{176}$ See, e.g., Article 4 of the Resolution 'L'arbitrage entre Etats et entreprises étrangères', adopted at the 18th Session of the Institut de Droit International in Santiago de Compostela, 4-14 September 1989, printed in (1990) ICSID Review at pp. 139, 141.

177 Article 16 has been deleted from the Annex and included (with a slightly modified wording, thus the previous version required that the set-off 'is' taken into account) in the new Rules in effect as of 1 January 1998 in the ICC's efforts to make the Rules more understandable and complete, see ICC Document No. $420 / 350$ of 8 October 1996 , at p. 20.

178 The problem is not eliminated with the new ICC Rules that have entered into force on 1 January 1998 since arbitrations pending on that date remain subject to the old rules on costs even if the parties have agreed to have the new ICC Arbitration Rules applied to their proceedings. 
to deal with the set-off or whether the set-off was conditioned upon the payment of the advance on costs. ${ }^{179}$

As in the case of cross-claims subject to a jurisdiction or different arbitration clause outlined above, ${ }^{180}$ the answer to this question requires a distinction between the substantive and the procedural plane. In jurisdictions such as Germany, ${ }^{181}$ the Netherlands ${ }^{182}$ and Switzerland, ${ }^{183}$ a declaration of set-off may not be made under a legal condition since the other party has a vital interest to know with certainty whether his claim has been extinguished through the unilateral declaration of setoff or not. The provisions on the increase of the advance on costs in the ICC Rules do not interfere with this principle. They must be qualified as being of a purely procedural nature. In fact, reference to them in the arbitration clause can be regarded as a procedural agreement of the parties relating to the treatment of setoff in case of a party's failure to pay the required advance on costs. By referring to the ICC Rules, the parties agree that the set-off shall only be entertained by the tribunal if the advance for the set-off has been paid. This follows from the interplay of Article 16 of the Internal Rules, providing that a set-off, for purposes of determining the advance of costs, is to be treated as a separate claim and section $2(\mathrm{~b})$ of the Appendix III (Schedule for Conciliation and Arbitration Costs), which provides that 'the submission of any claim to the arbitrator(s) shall be made only after at least half of the advance on costs ... has been satisfied'. ${ }^{184}$

The German Federal Supreme Court, in a long line of cases, has ruled that, in the context of set-off, "the parties may conclude procedural agreements in which one of the parties undertakes to comply with a certain procedural conduct ... If that party introduces a remedy in violation of the agreed upon procedural conduct, it may not be heard with it in the legal proceedings'. ${ }^{185}$ This principle may also be applied to the advance on costs in case of set-off under the old ICC Rules of Conciliation and Arbitration. ${ }^{186}$ Consequently, if the advance is not paid by the respondent, the tribunal has no jurisdiction to deal with the set-off. As in the case of set-off with a claim that is subject to a jurisdiction or different arbitration

179 See Reiner, supra n. 2, at p. 114, n. 36.

${ }^{180}$ See supra V(b)(i).

181 See s. 388 2nd sentence of the German Civil Code ('The declaration of set-off is without effect if it is put under a legal condition or a stipulation of time'); cf. also Palandt and Heinrichs, Bürgerliches Gesetzbuch (1988, 57 th ed.) § 388 , No. 1 .

${ }^{82}$ See Neiuwenhuis, Stolker and Valk, Burgerlijk Wetboek, Boeken 3, 5 en 6 (1994, 2nd ed.) Article 6: 127 , No. 1 in fine.

${ }^{183}$ See Honsell, Vogt, Wiegand and Peter, Obligationenrecht 1 (1996) Article 124, No. 3.

${ }^{184}$ Article 9(3) of the ICC Rules of Conciliation and Arbitration deals only with the "transmission of the file to the arbitrator'; it is therefore a purely technical rule relating to the internal procedure of the Secretariat and may not be taken as an indication for the agreed-upon effect of a party's failure to pay the advance on the tribunal's competence to entertain a plea of set-off.

${ }^{185}$ BGHZ 38, 254, 258 with reference to RGZ 160, 241 and BGH in (1953) Juristen-Zeitung at p. 153.

${ }^{186}$ cf. Reiner, supra n. 2, at p. 114, n. 36: ' . . fulfillment of the financial obligation [to pay the advance on costs fixed for the set-off] must be understood as an agreed-upon condition for the [procedural?] admissibility of the set-off' (translation by the author). 
clause, ${ }^{187}$ the set-off has to be dealt with in the ensuing enforcement procedures. The claimant may avoid these problems from the outset by paying the whole of the advance under Article 9(2) of the ICC Rules.

Under the new ICC Rules of Arbitration the situation is not so clear. The general thrust of the new Rules to make the system for the payment of the advances on costs more transparent and more efficient has led to a relaxation of the effect of a party's failure to pay its advance on costs. Article 30(4) of the new Rules provides that ' $[w]$ hen a request for an advance on costs has not been complied with, the Secretary General may direct the Arbitral Tribunal to suspend its work and set a time limit, on the expiry of which the relevant claims ... shall be considered as withdrawn'. It will be hard to take this as an indication for the parties' agreement on the procedural inadmissibility of set-off in case the party raising the plea has not paid the advance under Article 30(5) in connection with Article 30(3) of the new Rules. Rather, it must be assumed that the arbitrators have the authority to deal with the set-off but that the parties have delegated the power to decide on the inadmissibility to the Secretary General. However, it must be borne in mind that the Secretary General in these cases does not decide a legal issue that is reserved for the decision-making of the arbitrators. Rather, he merely renders an administrative decision leading to the withdrawal of the set-off by virtue of Article 30(4), a provision to the application of which the parties have agreed by referring to the ICC Rules of Arbitration. The problem remains, however, that under these circumstances, the arbitrators have to ignore the set-off even though the declaration of set-off during or prior to the arbitral procedure may have had led to the extinction of the claimant's claim on the plane of substantive law, which may cause problems in the enforcement stage. Again, the claimant may avoid this from the outset by paying the whole of the advance on costs pursuant to Article 30(3) 3rd sentence of the new ICC Arbitration Rules.

In spite of these considerations, the arbitrators in the ICC arbitrations mentioned above did not pursue the approach developed for the old ICC Rules. They found themselves unable, under the law applicable to the arbitration agreement, to interpret the provisions of the ICC Rules in the way just described. Instead, they dealt with the set-off defence introduced by the respondent even though the increased advance on costs was not paid by the respondent. They did this at their own expense, since they did not receive a higher fee even though the set-off required them 'to consider additional matters' as envisaged by Article 16 of the Internal Rules. However, it can be assumed that the arbitrators in these cases had no difficulty in realizing that the set-off defence was clearly unfounded so that it was easier for them to avoid the intricacies of procedural and substantive law and enforcement problems in the post-award phase from the outset by deciding on the set-off defence.

Only very few other arbitration rules contain provisions on the costs of set-off.

187 See supra V(b)(i). 
Thus, under Article 13 of the Stockholm Chamber of Commerce Arbitration Rules, the Arbitration Institute of the Chamber may fix a separate advance for a plea by way of set-off. Under the International Arbitration Rules of the Zurich Chamber of Commerce, the value in dispute is increased by the amount of the setoff if this defence relates to a non-connected claim. ${ }^{188}$ The rules of the WIPO, the DIS and the LCIA contain provisions on costs in case of counterclaims but do not deal with costs in case of set-off.

\section{CONCLUSION}

Set-off in international economic arbitration poses a variety of problems that range from balancing the parties' interests and basic procedural rights over the determination of cross-claims that do not fall within the jurisdiction of the arbitral tribunal and complicated problems of costs to complex issues of conflict of laws. In considering the procedural admissibility of set-off, the arbitrator often is confronted with the classical conflict of modern international arbitral procedure: balancing the parties' rights against the need for arbitral efficiency. The analysis of set-off with cross-claims that are subject to a jurisdiction or different arbitration clause and of set-off for which an increased advance of costs has not been paid has also revealed the basic dilemma of the law of set-off in the context of international arbitration: the conflict between the limited scope of the arbitration agreement and the inherent function of the set-off defence as a means for the global settlement of the debts outstanding between the parties. In these cases, international arbitrators must first ascertain whether the circumstances of the case before them do in fact require a discussion of this complex issue:

- Does the cross-claim really exist?

- Are the requirements met that the applicable law imposes for the validity of the set-off defence?

- Is the set-off excluded by express or implied agreement of the parties concluded in the initial contract or later or even during the arbitration?

- Is the set-off excluded by the law applicable to the set-off?

- Is the set-off excluded by the general principle of good faith, both on the plane of substantive and procedural law?

- If the cross-claim has been assigned to the respondent, was this assignment effected in bad faith, preventing the set-off under the applicable law?

- If the set-off defence is valid, can the scope of the arbitration agreement be extended to the cross-claim?

- In case the contracts are 'closely related', does a hearing of the draftsmen of the arbitration agreement or jurisdiction clause covering the cross-claim

\footnotetext{
${ }^{188}$ Article 2.1 Schedule for Arbitration Costs, Zurich Chamber of Commerce International Arbitration Rules,
} reprinted in Berger, supra n. 67 , at pp. $849,853$. 
reveal that both parties did in fact intend to have the cross-claim adjudicated in the same forum as the main claim?

For the remaining cases, the tribunal has to refuse to deal with the set-off for lack of jurisdiction over the cross-claim, knowing that the set-off has led to the extinction of claim and cross-claim on the plane of substantive law. This situation, however, is by no means limited to the arbitral process. German and English courts alike have long since acknowledged that the procedural aspects for invoking the set-off must be distinguished from the availability of set-off as a substantive defence. ${ }^{189}$

${ }^{189}$ See In re Milan Tramways Company; ex parte Theys [1882] Ch.D. 122 at 126; Stumore v. Campbell \& Co. [1892] 1 QB 314 at 316 et seq.; Hanak v. Green [1958] 2 QB 9 at 22; Derham, supra n. 1, at p. 5, stating that English Rules of the Supreme Court do not determine the availability of set-off but merely lay down the procedure for claiming the defence; see also German Federal Supreme Court in BGHZ 60, 85, 87 stating that 'in spite of its substantive effectiveness ... the court, for procedural reasons, may be prevented from taking into account the plea of set-off; $c f$. also Reithmann and Martiny, supra n. 61, No. 2498. 